\title{
Effect of Farm Categories on Quality and Quantity of Milk Produced by Different Crosses of Holstein-Friesian Cows
}

\author{
Tanni Chanda', M.K.I. Khan², G.C. Chanda ${ }^{3}$, G.K. Debnath ${ }^{3}$
}

10.18805/ag.RF-214

\begin{abstract}
Background: Farmers are not satisfied by the production performance of different crossbred Holstein-Friesian (HF) cows in Chattogram, Bangladesh. Therefore, the study was taken to find out the effect of farm categories on milk yield and milk constituents of different HF crossbred at Chattogram, Bangladesh.

Methods: This study was conducted from July 2014 to June 2015 in Chattogram Metropolitan Area (CMA), Potia, Mirsharai and Fatikchari upazilla (sub-district) of Chittagong, Bangladesh. For this study fourteen (14) commercial dairy farms in three different categories as $\mathrm{A}$ (50> milking cows), $\mathrm{B}(31>50$ milking cows), $\mathrm{C}(11>30$ milking cows) with 98 cows for each of the 3 crosses named as $50 \% \mathrm{HF} \times 50 \%$ Local $(\mathrm{L}), 75 \% \mathrm{HF} \times 25 \% \mathrm{~L}$ and $50 \% \mathrm{HF} \times 50 \%$ Sahiwal $(\mathrm{SH})$ at their third parity were selected. Farms under the same category were selected based on similarities in feeding and other management practices. Quality of raw milk was obtained by analyzing the milk samples collected from an individual animal of the selected farm at an interval of seven days by using a milk scanner (Lactostar, Model no. 3510, Funke Gerber, Germany) in the Laboratory of Dairy Science of Chattogram Veterinary and Animal Sciences University (CVASU).

Result: A significant difference $(P<0.05)$ in milk yield and constituents except lactose and minerals was observed among the same and different crossbreds of HF under different farm categories. The highest daily average milk yield and quality were observed in different crosses of farms belong category A, but their performances decreased gradually with poor management systems in farms belong to categories B and C. So, farm category has a significant effect on milk quality and quantity in different crosses of Holstein. This study would help the commercial dairy farmers in choosing suitable crosses of Holstein-Friesian for farms belong to different categories.
\end{abstract}

Key words: Category A (50>milking cows), Category B (31>50 milking cows), Category C(11>30 milking cows), Holstein crosses, Milk composition, Milk yield.

\section{INTRODUCTION}

In Bangladesh dairy has been emerging as a transformation from livelihood-oriented dairy toward enterprise-driven dairy while it can still be seen as a key source of income and livelihood for millions of people (Uddin et al. 2020). Holstein crossbred (Holstein $\times$ local zebu) and Sahiwal crossbred cattle (Sahiwal $\times$ local zebu) are two major crossbred used in commercial dairying in Bangladesh, although, the Holstein crosses is predominates (Haque et al. 2011). The milk production performance of $\mathrm{HF} \times \mathrm{L}$ crossbred cows under Bangladesh's condition substantially improved gradually over the decades (Bhuiyan, 2015). As a result, most of the commercial dairy farmers are using different ratios of HF crosses for higher quality and quantity milk production in their farms. The breeding procedure need to be adjusted for a steady genetic trend in the herd that is related to milk production (Iqbal et al. 2007). However, dairy farmers need to establish permanent financial management according to their farm size (Lopes et al. 2010) that is related to the selection of suitable crossbred (Singh, 2006).

The commercial dairy farmers of Chittagong are interested to rearing a higher blood percentage of Holstein crosses for increased milk production. Khan et al. (2014) stated that the milk production performance of the crossbred was higher in $F_{1}$ cows almost everywhere the same, but it was questionable for crossing with the Friesian one or two times or more. Siddiquee (2014) recommends that an
${ }^{1}$ Department of Dairy Science, Patuakhali Science and Technology University, Dumki, Patuakhali, Bangladesh.

${ }^{2}$ Department of Genetics and Animal Breeding, Chattogram Veterinary and Animal Sciences University, Khulshi, Chattagram4225, Bangladesh.

${ }^{3}$ Department of Dairy and Poultry Science, Chittogram Veterinary and Animal Sciences University, Khulshi, Chattagram-4225, Bangladesh.

Corresponding Author: Tanni Chanda, Department of Dairy Science, Patuakhali Science and Technology University, Dumki, Patuakhali, Bangladesh. Email: tanni@pstu.ac.bd

How to cite this article: Chanda, T., Khan, M.K.I., Chanda, G.C. and Debnath, G.K. (2021). Effect of Farm Categories on Quality and Quantity of Milk Produced by Different Crosses of HolsteinFriesian Cows. Agricultural Reviews. DOI: 10.18805/ag.RF-214.

Submitted: 05-07-2021 Accepted: 01-11-2021 Online: 22-12-2021

appropriate blood percentage of the exotic will be helpful to Bangladeshi farmers for higher milk yield in the peri-urban areas.

The commercial dairy sector of Chattogram, Bangladesh facing a lot of problems among them choosing a suitable cross of HF crosses for higher milk production and quality, according to the farm category is a major. However, no studies are associating both milk quality and traits with different farm categories related to Holstein Friesian (HF) 
Effect of Farm Categories on Quality and Quantity of Milk Produced by Different Crosses of Holstein-Friesian Cows

crosses. A study is required to find out the effect of farm category with milk quality and production performance of dairy crossbred cattle reared by the commercial dairy farmers of Bangladesh. Therefore, the study was conducted to maximize marketable milk yield with optimum desired quality to the producers for increasing farm profit with the objectives of (i) compare the quality and quantity of milk yield among different crossbreds of HF under different farm categories in commercial dairying; and (ii) to find out the correlations between categories of farms with milk yield and milk composition of different crossbreds of HF under commercial dairying in Chattogram, Bangladesh.

\section{MATERIALS AND METHODS}

\section{Study areas and study periods}

The study was conducted for a period of one year, from July 2014 to June 2015 in Chattogram Metropolitan Area (CMA) and Potia Upzilla, Potiya, Mirsharai and Fatikchari upazilla (sub- district) of Chittagong, Bangladesh.

\section{Selection of farms, crossbreds and number of animals}

A total of 14 farms, 3 belongs to category A (50+ milking cows), 3 belongs to category B (31-50 milking cows) and 8 belongs to category $C$ ( 11 to 30 milking cows) were randomly selected based on availability of target crossbreds, same feeding, housing, method of milking, disease preventive measures and other management practices. The category of farms was selected according to the Department of Livestock (DLS, 2014) Bangladesh. A total mixed ration or TMR was given to the animal. A total number of 294 dairy cows of which 98 cows from each crosses $50 \% \mathrm{HF} \times 50 \% \mathrm{~L}$; $75 \% \mathrm{HF} \times 25 \% \mathrm{~L}$ and $50 \% \mathrm{HF} \times 50 \% \mathrm{SH}$ were selected from the above mentioned farm at their third parity. Artificial insemination (ID) card was used by the farmer that supplied by the local livestock office, were considered for selection of the crossbred. The dairy rations of different feed combination having similar metabolic energy (ME) and crude protein (CP) were analyzed at the Poultry Research and Training Center (PRTC) of Chattogram Veterinary and Animal Sciences University (CVASU) and a pretested structured questionnaire was used to collect information on the management condition of the farm. Based on the feed analysis and farm management data, the different category farms were selected.

\section{Sample collection and analysis}

Milk production of an individual cow throughout the lactation period was recorded daily by the researchers and farm workers. For determination of milk quality, milk samples were collected from an individual selected animal of each farm at 7 days interval by collecting morning and evening samples together, It was then immediately brought to the laboratory in an ice box for chemical analysis and analysis was done for fat, protein, lactose, minerals and, SNF using milk scanner (Lactostar, Model no. 3510, Funke Gerber, Germany) in the Laboratory of Dairy Science of CVASU.

\section{Statistical analysis}

Collected data were edited using Microsoft Excel and the descriptive statistics were analyzed using the statistical analytical software (SAS, 2008). The following statistical model was used to estimate the mean with standard errors of all the studied parameters.

Where,

$$
Y_{i j k}=\mu+F i+B j+e_{i j k}
$$

$\mathrm{Y}_{\mathrm{ijk}}$ is the parameter's value.

$\mu=$ Overall mean.

$F_{i}$ is the effect of farm type.

$B_{j}$ effect of breed groups/Crosses.

$e_{i j k}$ is the random error distributed as $N(0, \sigma 2)$.

The mean differences were compared using the least significant difference (LSD) test (Steel et al.1997) at a 5\% level of significance.

\section{RESULTS AND DISCUSSION}

\section{Observed milk quality of different crossbreds under} different categories of farm

The daily average milk yield (Liter) and milk constituents based on the farm category and Holstein-Friesian crossbreeds are presented in Table 1. From Table 1, it's evident that there was a significant difference $(P<0.05)$ in milk yield among crosses and also in the same crosses under different farm categories. Besides, the average milk production was also differed significantly $(P<0.05)$ among the farm categories. Milk yield (Liter/day) of $75 \% \mathrm{HF} \times 25 \% \mathrm{~L}$ crossbred was the highest, whereas $50 \% \mathrm{HF} \times 50 \% \mathrm{~L}$ crossbred was the lowest irrespective of the farm categories. Milk yield increased when the proportion of exotic inheritance increased from 50 to 75 per cent was an agreement to Singh (2016). Significant $(P<0.05)$ difference in production performance of $75 \% \mathrm{HF} \times 25 \% \mathrm{~L}$ also may be attributed to the variations in the level of management was an agreement to Kumar et al. (2017) and Nath et al. (2016).

Observed milk fat percentage in different farm categories and crossbreds

There was a significant difference $(P<0.05)$ in fat percentage of milk among different crosses and the same crosses under different farm categories. The highest fat percentage was recorded in $50 \% \mathrm{HF} \times 50 \% \mathrm{~L}$ and the lowest in $75 \% \mathrm{HF} \times 25 \% \mathrm{~L}$ crossbred irrespective of farm categories. There were significant $(p<0.05)$ differences in fat percentage among the different crossbreds of HF. Milk fat percentage was highest in $50 \% \mathrm{HF} \times 50 \% \mathrm{~L}$ and the lowest for $75 \% \mathrm{HF} \times 25 \% \mathrm{~L}$ crossbred irrespective of farm categories. Our results were similar to the findings of Haile et al. (2009); Cheruiyot et al. (2018). Farm average fat percentage was significantly $(P<0.05)$ higher in farms belongs to category $A$ compared to farms belongs to category $B$ and $C$. Regular supply of fodder and experience inefficient feed management might be the cause for average higher fat percentages in farms belongs to category A compared to category $B$ and $C$. Yeamkong et al. (2010) findings that variability of fat across 
farm size could be associated with the availability of roughage and the ability of farmers to manage and utilize feed resources was similar to our results.

\section{Observed milk protein percentage in different farm categories and crossbreds}

There was a significant difference $(P<0.05)$ in the average protein percentage of milk among different farm categories. The highest protein percentage was recorded in $50 \% \mathrm{HF} \times 50 \% \mathrm{~L}$ and lowest in $75 \% \mathrm{HF} \times 25 \% \mathrm{~L}$ crossbred irrespective of farm categories. Our findings were similar to the results of Cheruiyot et al. (2018) and Haile et al. (2009). A non-significant difference was observed in protein percentage between $50 \%$ crosses of HF with Local (L) and Sahiwal (SH) under the same and different farm categories. Our findings were an agreement with Haile et al. (2009). The average protein percentage of different farm categories was differed significantly $(P<0.05)$. The average protein percentage was significantly higher in farms belongs to category A compared to $\mathrm{B}$ and $\mathrm{C}$. That difference might be attributed due to differences in management and feed supply of the farms under different categories. The farms belong to $B$ and $C$ have often changed their rations according to availability of roughage and meet the scarcity of forage with non-fiber higher energy concentrate feed compare to farms belongs to category $A$. Altering the nutrition by changing the proportion of protein in the diet has been shown to affect milk protein composition Tacoma (2016) was an agreement to us.

\section{Observed milk lactose percentage in different farm categories and crossbreds}

There was no significant difference in lactose content among different farms categories and crosses. Comparatively higher lactose content was found in $50 \% \mathrm{HF} \times 50 \% \mathrm{~L}$ crossbred under farm category $A$ and the lowest in $75 \% \mathrm{HF} \times 25 \% \mathrm{~L}$ cross under category $\mathrm{B}$ farm. Lactose percentage was comparatively higher in the case of $50 \%$ Holstein crosses with Local (L) and Sahiwal (SH) compare to $75 \%$ crosses of Holstein (HF) under different farm categories. But the differences were non-significant. Our findings were similar to Shibru et al. (2019) and Wangdi et al. (2016). The average lactose percentage was higher in farms belongs to category $A$ compared to farms belongs to category B and C. Supply of higher concentrate and imbalance of roughage and concentrate ratio in ration by the farms belong to category $B$ and $C$ and supply comparatively balanced ration with a proper ratio of roughage and concentrate in farms under category A might be the cause for the higher concentration of lactose under category A farms compare to B and C. Our findings were an agreement to Basset et al. (2012).

\section{Observed milk mineral percentage in different farm} categories and crossbreds

The mineral content of same and different HF crosses did not differ in the same and different farm categories (Table 1). The highest percentage of minerals were observed in $50 \% \mathrm{HF} \times 50 \% \mathrm{~L}$ crossbred and the lowest in $75 \% \mathrm{HF} \times 25 \% \mathrm{~L}$ crossbred irrespective of farm categories (Table 1). Furthermore, there were no significant differences $(P<0.05)$ observed in the mineral content of milk among different farm categories. Our findings were in agreement to Noori et al. (2014) and Gemechu et al. (2015).

\section{Observed milk SNF percentage in different farm categories and crossbreds}

In the case of lactose percentage of milk, there was no significant difference $(P<0.05)$ among the farm categories

Table 1: Milk quality and quantity of different crossbred under different farm categories.

\begin{tabular}{|c|c|c|c|c|c|c|}
\hline Crosses & MY (Liter/day) & Fat $\%$ & Protein \% & Lactose $\%$ & Minerals \% & SNF\% \\
\hline \multicolumn{7}{|c|}{ Farm category-A } \\
\hline $50 \% \mathrm{HF} \times 50 \% \mathrm{~L}$ & $10.94 \pm 3.781$ & $4.33^{\mathrm{a}} \pm 0.421$ & $3.44^{\mathrm{a}} \pm 0.160$ & $4.58^{N S} \pm 0.080$ & $0.75^{\text {NS }} \pm 0.083$ & $8.75^{\mathrm{a}} \pm 0.302$ \\
\hline $75 \% \mathrm{HF} \times 25 \% \mathrm{~L}$ & $13.56^{\mathrm{a}} \pm 8699$ & $3.82^{\mathrm{a}} \pm 0.266$ & 3. $38^{b} \pm 0.0856$ & $4.56^{N S} \pm 0.120$ & $0.72^{N S} \pm 0.635$ & $8.72^{a} \pm 0.136$ \\
\hline $50 \% \mathrm{HF} \times 50 \% \mathrm{SH}$ & $12.13^{\mathrm{a}} \pm 4.248$ & $4.15^{\mathrm{a}} \pm 0.361$ & $3.42^{\mathrm{a}} \pm 0.302$ & $4.54^{N S} \pm 0.139$ & $0.73^{N^{N S}} \pm 0.073$ & $8.72^{\mathrm{a}} \pm 0.219$ \\
\hline \multirow[t]{2}{*}{ Farm average } & $12.21 \pm 5.476$ & $4.10 \pm 0.369$ & $3.43 \pm 0.183$ & $4.56 \pm 0.113$ & $0.73 \pm 0.514$ & $8.73 \pm 0.219$ \\
\hline & ** & ** & ** & NS & NS & ** \\
\hline \multicolumn{7}{|c|}{ Farm category-B } \\
\hline $50 \% \mathrm{HF} \times 50 \% \mathrm{~L}$ & $10.83 \pm 4.152$ & $4.25^{\mathrm{b}} \pm 0.421$ & $3.43^{a} \pm 0.296$ & $4.58^{N S} \pm 0.073$ & $0.74^{\mathrm{NS}} \pm 0.084$ & $8.74^{\mathrm{a}} \pm 0.353$ \\
\hline $75 \% \mathrm{HF} \times 25 \% \mathrm{~L}$ & $12.61^{\mathrm{b}} \pm 4.318$ & $3.76^{b} \pm 0.317$ & $3.37^{b} \pm 0.140$ & $4.54^{N N} \pm 0.120$ & $0.72^{\mathrm{NS}_{ \pm}} \pm 0.077$ & $8.65^{c} \pm 0.250$ \\
\hline $50 \% \mathrm{HF} \times 50 \% \mathrm{SH}$ & $11.70^{\mathrm{b}} \pm 4.188$ & $4.01^{\mathrm{b}} \pm 0.336$ & $3.41^{\mathrm{a}} \pm 0.136$ & $4.55^{N S} \pm 0.116$ & $0.73^{N S} \pm 0.070$ & $8.68^{c} \pm 0.195$ \\
\hline \multirow[t]{2}{*}{ Farm average } & $11.71 \pm 4.220$ & $4.0 \pm 0.358$ & $3.40 \pm 0.190$ & $4.56 \pm 0.103$ & $0.73 \pm 0.327$ & $8.69 \pm 0.266$ \\
\hline & $* *$ & ** & $* *$ & NS & NS & $* *$ \\
\hline \multicolumn{7}{|c|}{ Farm category-C } \\
\hline $50 \% \mathrm{HF} \times 50 \% \mathrm{~L}$ & $10.68 \pm 4.192$ & $4.19^{c} \pm 0.358$ & $3.41^{\mathrm{a}} \pm 0.301$ & $4.56^{N S} \pm 0.113$ & $0.73^{\mathrm{NS}} \pm 0.069$ & $8.71^{c} \pm 0.264$ \\
\hline $75 \% \mathrm{HF} \times 25 \% \mathrm{~L}$ & $11.40^{c} \pm 4.276$ & $3.68^{c} \pm 0.257$ & $3.35^{b} \pm 0.179$ & $4.56^{N S} \pm 0.115$ & $0.72^{\mathrm{NS}_{ \pm}} \pm 0.057$ & $8.63^{c} \pm 0.286$ \\
\hline $50 \% \mathrm{HF} \times 50 \% \mathrm{SH}$ & $11.46^{c} \pm 2.933$ & $3.95^{c} \pm 0.335$ & $3.38^{a} \pm 0.180$ & $4.55^{N S} \pm 0.109$ & $0.73^{N S} \pm 0.062$ & $8.65^{c} \pm 0.292$ \\
\hline Farm average & $11.18 \pm 3.80$ & $3.94 \pm 0.317$ & $3.37 \pm 0.22$ & $4.56 \pm 0.112$ & $0.73 \pm 0.063$ & $8.65 \pm 0.281$ \\
\hline Level of significance & $\star *$ & $* *$ & $* *$ & NS & NS & $* *$ \\
\hline
\end{tabular}

Different letter in the same column differed significantly at $(P<0.05)$ level of significance. 
Effect of Farm Categories on Quality and Quantity of Milk Produced by Different Crosses of Holstein-Friesian Cows

Table 2: Correlation regression between milk yield and other milk constituents.

\begin{tabular}{lccccc}
\hline & MY & FAT & PRT & LAC & MIN \\
\hline MY & 1 & & & & \\
Fat & $-0.56^{* *}$ & 1 & & & \\
PRT & $-0.31^{* *}$ & $0.37^{* *}$ & 1 & & \\
Lac & $0.06^{* *}$ & $-0.07^{* *}$ & $-0.06^{* *}$ & $-0.12^{* *}$ & 1 \\
Min & $-0.60^{* *}$ & $0.06^{* *}$ & $-0.38^{* *}$ & $0.19^{* *}$ & $0.50^{* *}$ \\
SNF & $-38^{* *}$ & $0.04^{* *}$ & $-0.91^{* *}$ & 1 \\
\hline
\end{tabular}

(NS= non-significant, ${ }^{* *}=$ Significant at $5 \%$ level)

$\mathrm{MY}=$ Milk yield, $\mathrm{PRT}=$ Protein, $\mathrm{LAC}=$ Lactose, $\mathrm{MIN}=$ Mineral, $\mathrm{SNF}=$ Solids not fat .

and crossebreds (Table 1). The highest lactose percentage was found in $50 \% \mathrm{HF} \times 50 \% \mathrm{~L}$ crossbred of farms belong to category $\mathrm{A}$ and the lowest in $75 \% \mathrm{HF} \times 25 \% \mathrm{~L}$ crossbred in farms belong to category $B$ (Table 1 ). Our findings were similar to Shibru et al. (2019) and Wangdi et al. (2016). The average lactose percentage was highest in farms belongs to category $\mathrm{A}$ compared to categories $\mathrm{B}$ and $\mathrm{C}$ (Table 1). This may be attributed to the energy balance difference among farm categories was an agreement with Costa et al. (2019).

\section{Correlation with milk yield and other milk constituent}

From the correlation regression (Table 2) it was found that correlation with milk production and milk composition (fat, protein, lactose, mineral SNF) has a great impact on dairy cattle in different farm categories. In this study, most of the milk traits showed a negative strong significant $(P<0.05)$ correlation with milk yield, fat $(-0.560)$, protein $(-0.307)$, minerals $(-0.602)$ and SNF $(-0.379)$ and a weak positive significant $(P<0.05)$ correlation were observed between milk yield with lactose (0.06). Sourabh et al. (2017) also reported that a negative correlation between milk yield and major milk constituents. These findings indicate that selection of crosses with increased blood level of HF for higher milk production may tend to decline milk composition was an agreement with Alphonsus and Essien (2012).

\section{CONCLUSION}

It is revealed that there were a significant influence of farm categories on the quality and quantity of milk. A significant difference was also found in the case of quality and quantity of milk in the same crosses under the different farm categories. The quality and quantity of milk production were better in farms belong to category A compared to $B$ and $C$. Though, daily average milk yield per cow was highest in $75 \% \mathrm{H} \times 25 \% \mathrm{~L}$ crossbred compare to other crosses. However, the qualities with the quantity of milk remain constant for $50 \% \mathrm{HF} \times 50 \% \mathrm{~L}$ crossbred and varied in $75 \% \mathrm{H} \times 25 \% \mathrm{~L}$ and $50 \% \mathrm{HF} \times 50 \% \mathrm{SH}$ crossbreds irrespective of farm categories. Most of the commercial dairy farms of Bangladesh belong to category $\mathrm{C}$. Therefore, it can be said that, starting a commercial dairy farm with the $50 \% \mathrm{HF} \times 50 \% \mathrm{~L}$ crossbred would be suitable for their profitability. However, $75 \% \mathrm{HF} \times 25 \% \mathrm{~L}$ and $50 \% \mathrm{HF} \times 50 \% \mathrm{SH}$ crossbreds were suitable for category A farms, where framers had a long experience for managing dairy cows but these crosses can also be reared in the rest of the farm categories by improving their knowledge for management and feeding practices for dairy cattle. This study discovered the rearing of $50 \% \mathrm{HF} \times 50 \% \mathrm{~L}$ crossbred can be beneficial for all the farmers as the dairy business mainly depends on the quality and quantity of milk produced. This study will help the researchers to uncover the critical areas of dairying.

\section{REFERENCES}

Alphonsus, C. and Essien, I.C. (2012). The relationship estimates amongst milk yield and milk composition characteristics of Bunaji and Friesian $\times$ Bunaji cows. African Journal of Biotechnology. 11(36): 8790-8793,

Basset, M.A., Huque, K.S., Sarker, N.R., Hossain, M.M., Islam, M.N. (2012). Effect of season, genotype and lactation on milk yield and composition of local and crossbred dairy cows reared under different feed base region. Bangladesh Journal of Livestock Research. 19(1-2): 50-65.

Bhuiyan, A.K.F.H., Rashid, M.M., Khan, R.A., Habib, M.A., Bhuiyan, M.S.A., Faiz, M,A., (2015). Progeny tested bull production for dairy cattle development in Bangladesh. Bangladesh Journal of Animal Science. 44: 106-112.

Cheruiyot, E.K., Bett, R.C., Amimo, J.O., Mujibi, FDN. (2018). Milk composition for admixed dairy cattle in Tanzania. Frontiers of Genetics. 9: 142-148.

Costa, N.W., Sneddon, L., Shalloo, M., Franzoi, M., De Marchi. (2019). Penasa invited review: Milk lactose-Current status and future challenges in dairy cattle. Journal of Dairy Science. 102(7): 5883-5898.

DLS (2014). Annual Report on Livestock, Division of Livestock Statistics, Ministry of Fisheries and Livestock, Farmgate, Dhaka, Bangladesh.

Gemechu, T., Beyene, F. and Eshetu, M. (2015). Physical and chemical quality of raw cow's milk produced and marketed in Shashemene Town, Southern Ethiopia. ISABB Journal of Food and Agricultural Science. 5(2): 7-13.

Haile, A., Joshi, B.K., Ayalew, W., Tegegne, A., Singh, A., Yilma, Z. (2009). Genetic evaluation of Ethiopian Boran cattle and their crosses with Holstein Friesian for milk constituent traits in central Ethiopia. Journal of Cell and Animal Biology. 12(10): 171-176.

Haque, M.N., Haque, M.R., Parvin, A., Hussain, MM. (2011). Productive and reproductive performance of different Crossbred cattle at Sylhet Govt. dairy farm. Progressive Agriculture. 22(1-2): 47-54. 
Effect of Farm Categories on Quality and Quantity of Milk Produced by Different Crosses of Holstein-Friesian Cows

Iqbal, A., Bhuiyan, A.K.F.H., Bhuiyan, M.S.A. (2007). Estimation of genetic trends for some economic traits in dairy cattle. Bangladesh Journal of Animal Science. 36: 1-8.

Khan, M.K.I., Blair, H. and Lopez-Villalobos, N. (2014). Economic values for traits in a breeding objective for dairy cattle in Bangladesh. Indian Journal of Animal Sciences. 84(6): 682-686.

Kumar, R., Das, A.K., Raja, T.V., Rathee, S.K., Dubey, P.P., Prakash, B. (2017). Performance of crossbred cattle (HF $\times$ Sahiwal) under tropical farming conditions of Punjab. Indian Journal of Animal Sciences. 87(11): 1402-1405.

Lopes, M.A., Dias, A.S., Carvalho, F.M., Lima, A.L.R., Cardoso, M.G., Carmo, E.A. (2010). Economical results of milk production systems with different technological levels in the area of Lavras, Minas Gerais, Brazil in the years 2004 and 2005. Revista Bras de Agroci, 16: 125-132.

Nath, S.K., Bhowmik, D.K., Rokonuzzaman, M., Afri, K., Dashand, A.K., Alam, M.K. (2016). Production performance of different cross breeds of milch cow in Mithapukur upazilla, Rangpur. International Journal of Advance Multidiciplinary Research. 3(6): 29-33.

Noori, M., Ranjbar, S., Nazari, R., Jafari, M. (2014). The relationship between feed composition and milk qualification in some Iranian Grazieries. International Journal of Food Science and Nutritional Engineering. 4(3): 55-65.

SAS (2008). Statistical Analysis Systems Institute. Version 9.1, SAS Institute Inc., Cary, North Carolina, USA.

Siddiquee, N.U., Bhuiyan, M.S.A., Rahman, A.K.M.A., Amin, M.R., Bhuiyan, A.K.F.H. (2014). Suitability of temperature and tropical crossbred dairy cattle under peri- urban production system in Bangladesh. Animal Review. 1(2): 26-36.

Shibru, D., Tamir, B., Kasa, F., Goshu, G. (2019). Effect of season, parity, exotic gene level and lactation stage on milk yield and composition of Holstein Friesian crosses in central highlands of Ethiopia. European Journal of Experimental Biology. 9: 4-15.
Singh, C.V. (2016). Cross-breeding in cattle for milk production: Achievements, challenges and opportunities in India- A review. Advances in Dairy Research. 4(3):158-163

Singh, H. (2006). Impact of crossbreeding technology on economic efficiency of dairy farming in Kashmir valley- A regional analysis. Indian Journal of Regional Science. 38(1): 82-90.

Sourabh, Y., Kumar, C.S, Shanker, S.S., Sudheer, J. (2017). Correlation between milk constituent tend somatic cell counts in Holstein Friesian crossbred cattle. Inter. Journal of Agricultural Science. 9(7): 3840-3842.

Steel, R.G.D., Torrie, J.H., Dickey, D.A. (1997) . Principles and Procedures of Statistics: A Biometrical Approach. $3^{\text {rd }}$ edition. McGraw-Hill, Boston.

Tacoma, R., Fields, J., Ebenstein, D.B., Lam, Y.W., Greenwood, S.L. (2016). Characterization of the bovine milk proteome in early-lactation Holstein and Jersey breeds of dairy cows. Journal of Proteomics. 130: 200-210.

Uddin, MM. Akter, A., Khaleduzzaman, A.B.M., Sultana, M.N (2020). Forecasting milk production in Bangladesh toward achieving self-sufficiency. Livestock Research for Rural Development. 32(5). http://www.Irrd.org//rrd32/5/moham32081.html.

Wangdi, J., Zangmo Karma, T., Mindu, Bhujel, P. (2016). Compositional quality of cow's milk and its seasonal variations in Bhutan. Livestock Research on Rural Development. 28(1): 62-68.

Yeamkong, S., Koonawootrittriron, S., Elzo, M.A., Suwanasopee, T. (2010). Effect of experience, education, record keeping, labor and decision making on monthly milk yield and revenue of dairy farms supported by a private organization in Central Thailand. Asian-Australasian Journal of Animal Science. 23: 814-824. 